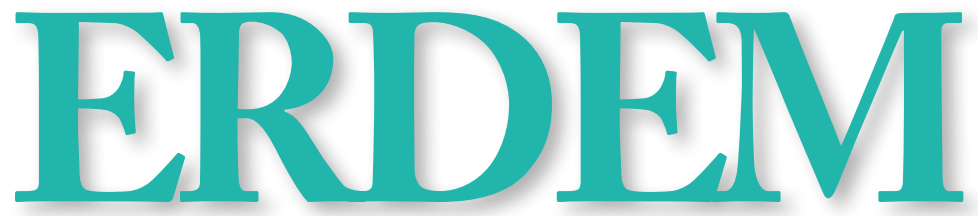

İNSAN VE TOPLUM BİLİMLERİ DERGİSİ

Münire Kevser BAŞ

Poetik Bir Metin Olarak Ebubekir Eroğlu’nun

"Yol Elçisi" Şiiri

Evşen ÇERKEŞLİ

Kurtuluş Savaşı ve Cumhuriyet İdeolojisini Edebî

Düzlemde Okumak: Dikmen Yıldızı Örneği

Hivren DEMIR ATAY

Tekerlerden Tekrarlara Gamba’da Dönüş ve Dönüşüm

Selma GÜNAYDIN

Edebî Bir Siyer Örneği Olarak Cöle İnen Nửun

Kaynakları

Mustafa GÜNDÜZ

Türk Eğitim Sisteminde Aşırı Militarist

Uygulamanın Başlaması (1926-1947)

Nagihan GÜR

Edebiyat Tarihi Yazımında Bir Kaynak Olarak

Takrizler ve Sıra Dışı İki Örnek

Osman ÖZEN - Kemalettin KUZUCU

Türk Basın Tarihinde Artin Asaduryan Matbaası ve

Matbaada Basılan Süreli Yayınlar

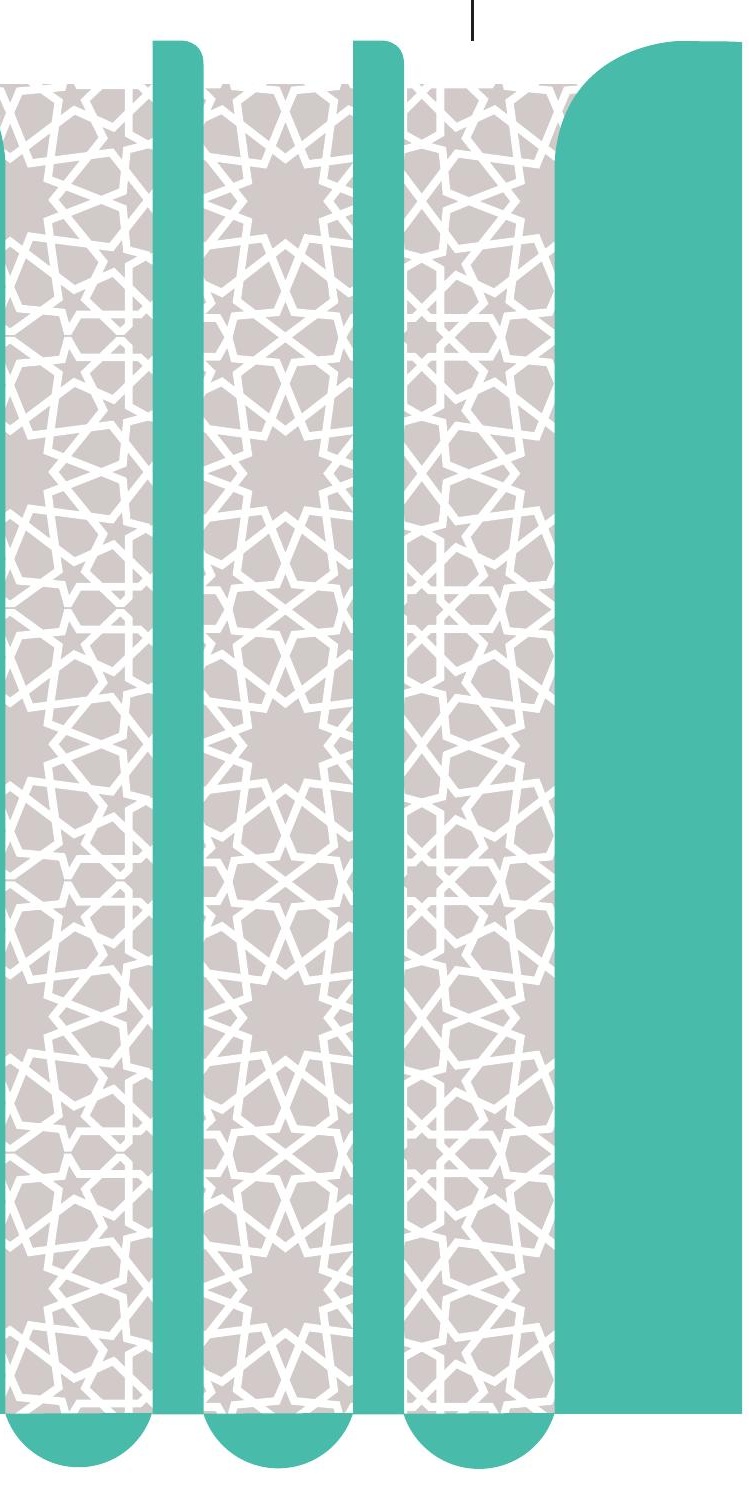




\section{ERDEM}

İNSAN VE TOPLUM BİLIMLERI DERGİSİ

JOURNAL OF HUMANITIES AND SOCIAL SCIENCES

Atatürk Kültür Merkezi tarafindan yayımlanan Erdem, insan ve toplum bilimleri alanında makalelere yer veren, hakemli bir uluslararası dergidir.

Haziran ve aralık aylarında olmak üzere yılda iki sayı çıkar.

Erdem, EBSCO, MLA ve TÜBİTAK/ULAKBİM SBVT tarafindan dizinlenmektedir.

Erdem, published by Atatürk Culture Centre, is a peer-reviewed international journal that publishes articles on humanities and social sciences.

It is published twice a year in June and December

Erdem is indexed in EBSCO, MLA and TÜBİTAK/ULAKBİM SBVT.

Görüş ve önerileriniz için editörlerimizle iletişime geçebilirsiniz.

For comments and suggestions you may contact our editors.

erdemdergisi@gmail.com 
Kültür yayıncılığın öncüsünden

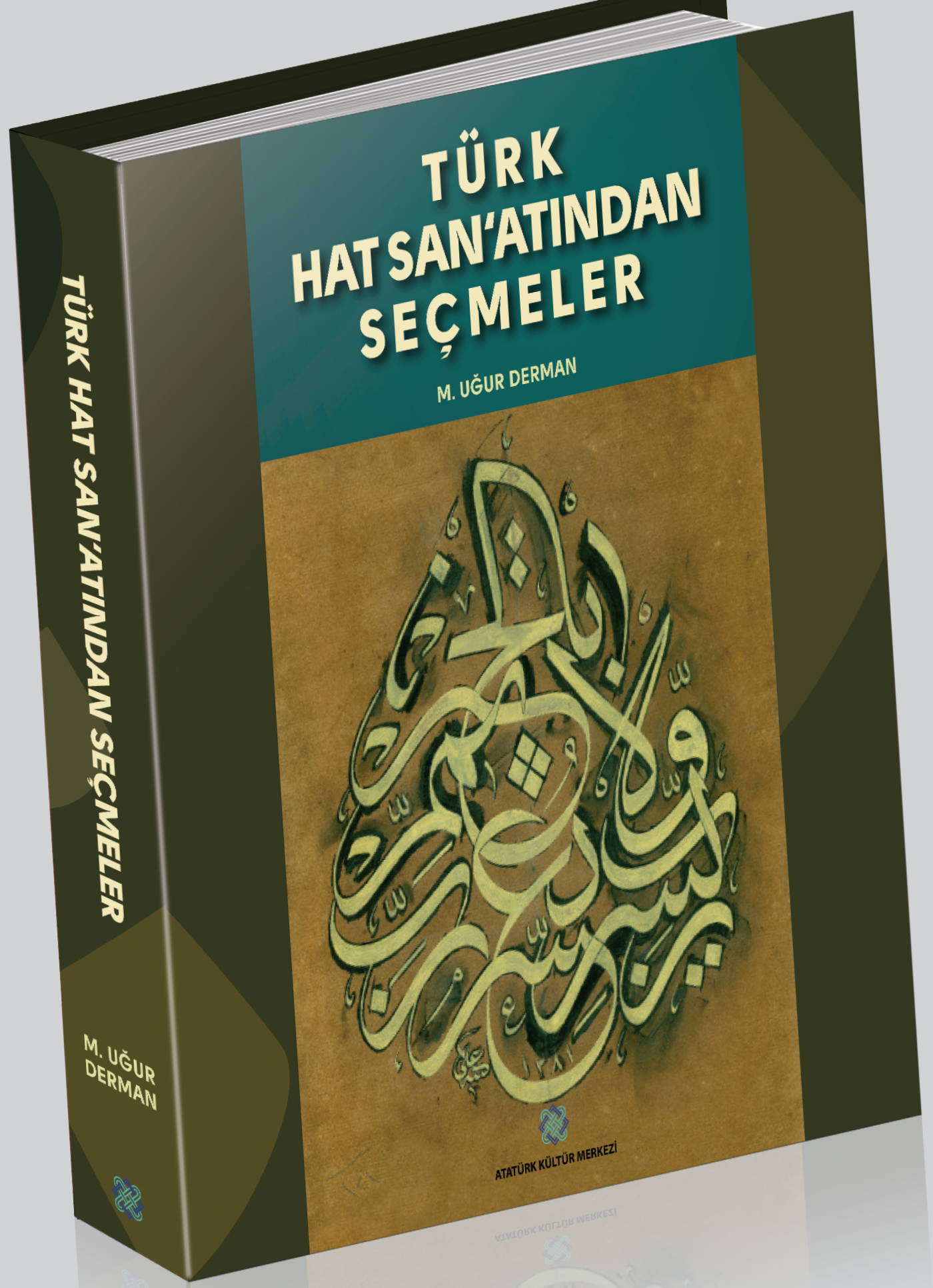




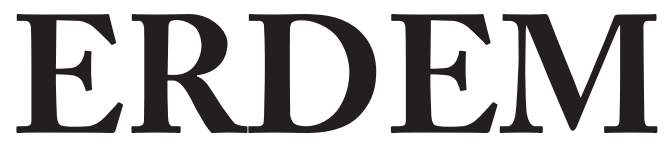

İnsan ve Toplum Bilimleri Dergisi

Journal of Humanities and Social Sciences

SAYI 71-72 • ARALIK 2016 - HAZIRAN 2017

ATATÜRK KÜLTÜR, DIL VE TARIH YÜKSEK KURUMU ATATÜRK SUPREME COUNCIL FOR CULTURE, LANGUAGE AND HISTORY

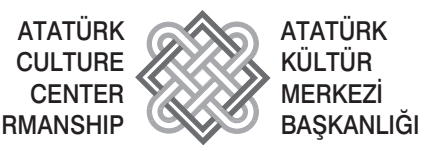




\section{ERDEM}

İnsan ve Toplum Bilimleri Dergisi

Journal of Humanities and Social Sciences

\section{DANIŞMA KURULU/ADVISORY BOARD}

Prof. Dr. Hakkı ACUN (Gazi Üniversitesi)

Prof. Dr. Hüseyin AKKAYA (Cumhuriyet Üniversitesi)

Prof. Dr. Âdem CEYHAN (Celâl Bayar Üniversitesi)

Prof. Dr. Hamza ÇAKIR (Erciyes Üniversitesi)

Prof. Dr. Mustafa ÇiçEKLER (İstanbul Medeniyet Üniversitesi)

Prof. Dr. Nurettin DEMIR (Hacettepe Üniversitesi)

Prof. Dr. Hayati DEVELI (İstanbul Üniversitesi)

Prof. Dr. Esin KÂHYA (Emekli öğretim üyesi)

Prof. Dr. Ramazan KAPLAN (Ankara Üniversitesi)

Prof. Dr. Alâattin KARACA (Muğgla Üniversitesi)

Prof. Dr. Selçuk MÜLAYIM (Marmara Üniversitesi)

Prof. Dr. Ahmet Yaşar OCAK (TOBB Üniversitesi)

Prof. Dr. Öcal OĞUZ (Gazi Üniversitesi)

Doç. Dr. Mehmet BİRGÜL (Uludağ Üniversitesi)

Doç. Dr. İdris Nebi UYSAL (Karamanoğlu Mehmetbey Üniversitesi) 


\section{ERDEM}

SAYI 71-72 • 2016-2017

Kurucu/Founder

Ord. Prof. Dr. Aydın SAYILI (1913-1993)

Sahibi/Owner

Atatürk Kültür Merkezi adına Başkan

Zeki ERASLAN

Yayın Kurulu/Editorial Board Prof. Dr. Muhammet HEKIMOĞLU

Prof. Dr. Güray KIRPIK

Doç. Dr. Bilal ÇAKICI

Uzm. Ömer ÇAKIR

Yüksek Kurum Uzm. Murat Altan ERİK

Yüksek Kurum Uzm. Yrd. Ömer GÖK

Yazı İşleri Müdürü/Managing Editor

Başkan Yardımcısı Şaban ABAK

Editörler/Editors

Yüksek Kurum Uzm. M. Altan ERİK

Uzm. Yrd. Ömer GÖK

İngilizce Özetler/English Abstracts Ayşegül ÖZDOĞAN

Yönetim Yeri/Managing Office Ziyabey Caddesi No: 19 Balgat 06520 Ankara, TÜRKIYE

Tel.: +903122843425 erdemdergisi@gmail.com www.akmb.gov.tr

GrafikTasarım/Graphic Design Grafiker Grafik-Ofset Matbaacılık

Reklamcılık San. ve Tic. Ltd. Şti Mustafa YAVUZ

Bask1/Print

Grafiker Grafik-Ofset Matbaacılık Reklamcılık San. ve Tic. Ltd. Şti. www.grafiker.com.tr

Yayın Türü/Publication Type Süreli Yayın

Yılda İki Sayı Çıkar ISSN 1010-867X

Baskı Tarihi/Print Date Haziran 2017
Değerli okurlar,

Erdem'in 71 ve 72 . sayıları ile karşınızdayız. Ülkemizde yaşanan hain darbe girişimi, tüm kamu kurumlarını derinden etkilediği gibi Kurum olarak bizim çalışmalarımızı da sekteye uğratmıştır. Bu sebeple Haziran 2016'da çıkaracağımız 71. sayıyı ancak 72. sayı ile birlikte siz değerli okuyucularımıza takdim ediyor, bundan sonra böyle gecikmelerin yaşanmamasını umuyoruz.

Sevgili okurlar, bu sayımızda edebiyat, basın ve eğitim tarihini ilgilendiren yazıların yanı sıra Selma Günaydın’ın “Edebî Bir Siyer örneği Olarak Çöle İnen Nur'un Kaynakları"nda Necip Fazıl Kısakürek; Doç. Dr. Münire Kevser Baş'ın "Poetik Bir Metin Olarak Ebubekir Eroğlu'nun 'Yol Elçisi' Şiiri”nde ise Ebubekir Eroğlu gibi kültür dünyamızın öncü isimlerinin eserleriyle ilgili inceleme yazılarını da muhtevi yedi makaleye yer verilmiştir. Kültür ve edebiyat tarihimize 1ş1k tutan birbirinden değerli bu makalelerin siz değerli okurlarımız tarafindan ilgiyle karşılanacağını ümit ediyoruz.

Dün olduğu gibi bugün de Erdem dergisi niceliği değil, niteliği önemseyen anlayışını devam ettiriyor. İki sayı birlikte çıkarmamıza rağmen bu anlayışımızdan yine taviz vermedik. Onlarca makaleden oluşan ancak okunmayan dergiler arasinda olmaktansa sayica az fakat özgün ve yetkin makaleler içeren bir dergi olmak tercihimizdir. Bu şiarla hareket ediyor ve makale seçimlerinden hakem atamalarına değin birçok aşamayı titizlikle yürütüyoruz. Bu noktada sizlerden gelecek eleştirilere de açık olduğumuzu bildirmek isteriz. Daha iyiye ve güzele yol almak için tüm yazar ve okurlarımızin desteğine talibiz.

Gelecek sayılarda buluşmak dileğiyle.

İyi okumalar,

\section{Şaban ABAK}




\section{ERDEM}

Say1 71-72 • Aralık 2016-Haziran 2017

\section{İÇINDEKILER/CONTENTS}

\section{Münire Kevser BAŞ}

Poetik Bir Metin Olarak Ebubekir Eroğlu'nun “Yol Elçisi” Şiiri

Ebubekir Eroğlu's Poem "Yol Elçisi” As a Poetic Text

\section{Evşen ÇERKEŞLI}

Kurtuluş Savaşı ve Cumhuriyet İdeolojisini Edebî

Düzlemde Okumak: Dikmen Yıldızı Örneği

The War of Independence and The Republican Ideology in

Literary Level: Dikmen Yıldizı Example

\section{Hivren DEMIR ATAY}

Tekerlerden Tekrarlara Gamba'da Dönüş ve Dönüşüm

From Bicycles to Cycles: Return and Transformation in Gamba

\section{Selma GÜNAYDIN}

Edebî Bir Siyer Örneği Olarak Çöle İnen Nư'un Kaynakları

Roots of Çöle İnen Nur As a Literary Example of Siyar

\section{Mustafa GÜNDÜZ}

Türk Eğitim Sisteminde Aşırı Militarist Uygulamanın Başlaması (1926-1947)

Starting Excessive Militarism in The Turkish Educational System (1926-1947)

\section{Nagihan GÜR}

Edebiyat Tarihi Yazımında Bir Kaynak Olarak Takrizler ve Sıra Dışı İki Örnek

Takriz Texts as a Source of Literary History Writing and Two Unusual Examples

\section{Osman ÖZEN - Kemalettin KUZUCU}

Türk Basın Tarihinde Artin Asaduryan Matbaası ve Matbaada Basılan Süreli Yayınlar ..... 117-138 Periodical Publishing Works and Artin Asaduryan Press in Turkish Press History

Yayın İlkeleri.

Editorial Principles 


\title{
Türk Eğitim Sisteminde Aşırı Militarist Uygulamanın Başlaması (1926-1947)
}

\author{
MUSTAFA GÜNDÜZ*
}

\begin{abstract}
ÖZ
Modern devletin icadıyla zorunlu eğitim, zorunlu askerlik ve vatandaşlık uygulamaları arasında mutlak bir ilişki ve etkileşim meydana geldi. Devlete sadık vatandaş yaratmanın yolu büyük ölçüde disiplinli, merkezî, kontrollü zorunlu eğitimden geçiyordu. Büyüklüğün, geniş ölçüde askerî güce endekslendiği 19. yüzyılda, asker sayısının artırılmas1 ve toplumsal mobilizasyon için eğitim en kullanışlı araçtı. Bu sebeple askerî dersler, ritüeller ve askerliği sevdirici uygulamalar eğitim programlarına eklendi. Bazen askerlik yalın halde programlarda görülürken bazen de Beden Eğitimi,Jimnastik, Tarih, Coğrafya gibi derslerin içerisinde verildi. 19. yüzyılın ikinci yarısından itibaren Osmanlı eğitimi de bu gelişmelerin dışında değildi. I. Dünya Savaşı sırasında yoğunlaşan militer eğitim ve paramilitarist örgütler, Cumhuriyet döneminde yeni bir boyut kazandi. 1926 sonrasinda askerlik zorunlu ders oldu, 1935 sonrasında bütün eğitim kademelerinde 20 günlük kamp hayatını da içeren bir uygulamaya dönüştü. Bu günün toplum ve zihin dünyasının biçimlenmesinde önemli rolü olan Askerlik Dersi, fazla araştırılmayan bir konudur. Bu makalede, birincil kaynaklar kullanılarak, 1926-1947 arasındaki Askerliğe Hazırlık dersi uygulaması incelenmiştir.
\end{abstract}

Anahtar sözcükler: Eğitim ve Militarizm, Paramilitarizm, Beden Eğitimi, Türk Ĕ̆itim Sistemi.

G ğitimin toplumu dönüştürücü bir güç ve araç olarak keşfedilmesi ve zorun-
lu hale getirilmesi Avrupa'da endüstri devriminin ilk zamanlarına kadar

Doç. Dr., Yıldız Teknik Üniversitesi, Eğitim Bilimleri Bölümü/İSTANBUL

E-posta: mgunduz@yildiz.edu.tr 
gider. ${ }^{1} \mathrm{Bu}$ süreçte eğitim modern öncesi dönemden belirgin yapısal farklılıklar kazand. Başta eğitime, modern ulus-devlet formasyonunun bürokrasi, şehirleşme, endüstrileşme ve teknoloji yeniliklerini sağlama ve sürdürme misyonu yüklendi. Bu misyonun gerçekleştirilebilmesi için eğitimin yapisında gerçekleşen ve eğitimi modern kılan nitelikler zorunluluk, devlet kontrolü, karma, laik ve merkeziyetçilik idi. Modern eğitimin kimliğini oluşturan bu unsurlar Toffler'ın Sanayi Devrimi'ni izleyen dönemde teknolojik gelişmenin ve yeni toplumsal yapının temel karakterleri olarak belirlediği "standardizasyon, senkronizasyon, yoğunlaşma, merkezileşme ve uzmanlaşma”" özellikleriyle örtüşüyordu. Bunlara 19. yüzyılın başlarında milliyetçilik de ilişti. Eğitim, geleneksel devlet yapısının modernleştirilmesi, milliyetçiliğin inşası ve yaygınlaştırılmasında bir mite dönüşürken zorunlu askerlik ${ }^{3}$ de devletlerin vazgeçilmezi haline geldi. Toplumun uzun süreli zorunlu askerliğe ikna edilmesi kolay değildi. Böylece milliyetçilik, zorunlu askerlik ve zorunlu eğitim arasında sıkı bir bağ meydana geldi. Bu bağ "militarizm" olgusunu yarattı. Milliyetçilik ve militarizm son iki yüzyllın kaderini tayin etmiş ve birbirini tamamlayarak iç içe geçmiş ideolojiler olarak belirdi. Askerî tarihin meşhur ve itibarlı tarihçilerinden Alfred Vagts'a göre "modern bir fenomen olarak militarizm Fransız İhtilali'yle başlayan zorunlu, kamusal askerliğin doğuşuyla bağlantılı bir gelişmedir."

Michael Mann militarizmi, "askerî meseleleri diğer bütün konulardan öncelikli görmek, savaşı ve savaş hazırlığını normal ve arzu edilir durum olarak kabul etmek" ${ }^{5}$ olarak tanımladıktan sonra, zorunlu askerliği bir tür militarist gelişme olarak görür. Konunun teorisyenlerinden Eleone ise militarizmi "toplumların ve vatandaşların askerî değerlere (hiyerarşi, itaat, güç kullanma vb.) adaptasyonu" olarak tarif eder. Kişilerin meselelerini çözmede askerî yöntemlerin etkili olduğunu düşünmesi militarist davranışların tanımlanmasında en belirgin durumdur. ${ }^{7}$ Militer zihniyet ve davranış toplumun yeme içme alışkanlıklarından giyinme biçimlerine varıncaya kadar her boyutunda hissedilir hale gelir. Militarizm ve eğitimin iş birliği sivillerin potansiyel as-

1 James Van Horn Melton, Absolutism and the Eighteenth-Century Origins of Compulsory Schooling in Prussia and Austria, Cambridge University Press, Cambridge 1988, s. XIII.

2 Alvin Toffler, Third Wave, New York, Morrow, 1980.

3 Arming the State: Military Conscription in the Middle East and Central Asia, 1775-1925, (Ed.: Erik J. Zürcher), I.B. Tauris, London 1999.

4 Alfred Vagts, A History of Militarism: Civilian and Military, Meridian Books 1959, s.41.

5 Michael Mann, "The roots and contradictions of modern militarism", States, War and Capitalism, Blackwell, Oxford 1992, s.166.

6 Cynthia Enloe, Globalization \& Militarism: Feminists Make the Link, Rowman \& Littlefield, Lanham 2007 , s.4.

7 Nancy Taber, "Intersecting discourses of militarism: military and academic gendered organizations", International Journal of Lifelong Education, Vol. 34, No.2, 2015, s.232. 
ker olmalarını öngörür. Bunun somut örneğini I. Dünya Savaşı öncesinde Almanya'da görüldü. ${ }^{8}$ Savaş yıllarında ve sonrasında askerlik hizmeti olmadan militarist bir toplum yaratma eylemleri başlamıştı. "Eğitim ve askerlik Fransa’da köylülerin Fransız'a dönüşmesi sürecinde merkezî rol oynarken," Türkiye'de de modernleşmenin ve Türk milliyetçiliğinin gelişmesinde etkili olmuştur. Ordu yalnızca "ulus-devletin vatandaş yaratma projesinin aracı olmakla kalmamış, kamusal eğitimi de şekillendirerek" ${ }^{10}$ tek-tipçi, bireysellikten uzak, demokratik normlara uzak bir toplum oluşmasına sebep olmuştur.

Militarizm, Vagts'ın belirttiğine göre, "savaş zamanlarından çok barış zamanlarında zenginleşir." ${ }^{11} \mathrm{Bu}$ süreçte sivil toplum kuruluşları, dinî mekânlar ve zorunlu eğitim militarizmin yaygınlaşmasına hizmet eder. Langdon-Davis 18. yüzyılda modern eğitim şekillenirken "okulların zorunlu askerliğin eşiği olarak yapılandırıldığını” ${ }^{\prime 2}$ iddia eder. Okulların askerliğe hazırlık mekânı olarak tasarlanmasında en somut gelişme programa konulan beden eğitimi ve izcilik olmuştur. Toplu fiziksel eğitim, jimnastik ve izcilik Foucoult'cu bir yaklaşımla "iktidarın bedenleri biçimlendirme ve dönüştürme"13 tezine mesnet olmakla birlikte, militarizmin görülür yanını temsil etmiştir. ${ }^{14}$ Bunun yanında gösterişli millî bayram kutlamaları, okul oyunları, yürüyüşler ve marşlarla edebî metinler militarizmi besleyen uygulamalardır. Başlangıçta, spor eğitimi sağlıklı beden beklentisinden ziyade irade ve karakter eğitiminin parçası olarak verilmişti.

Zorunlu eğitimin ortaya çıktığı Prusya'nın ardından Rusya, Avusturya-Macaristan ve diğer Avrupa ülkelerinin 19. yüzyıl sonu eğitimlerine bakıld1ğında militarist uygulama örnekleri görülür. Özellikle Almanya ${ }^{15}$, İngiltere, İskoçya ${ }^{16}$, Finlandiya, Hollanda ${ }^{17}$ ve dünyanın diğer ülkelerinden Çin, Ja-

8 Ute Frevert, A Nation in Barracks, Modern Germany, Military Conscription and Civil Society, Oxford: Berg, 2004, s.47.

9 Eugene Weber, Peasants into Frenchmen: The Modernization of Rural France, 1870-1914, Stanford University Press, Stanford 1976, s.295.

10 Ayşegül Altınay, Tanıl Bora, "Ordu, Militarizm ve Milliyetçilik", Modern Türkiye’de Siyasî Düșünce, Milliyețiilik, C.4, İletişim Yayınları, İstanbul 2002, s.141.

11 Vagts, age, 1959, s.15.

12 Langdon, Davies, Militarism in Education: A Contribution to Educational Reconstruction, 1919, s.149.

13 Vincent Stolk, Willeke Los ve Wiel Veugelers, "Physical education for citizenship or humanity? Freethinkers and natural education in the Netherlands in the mid-nineteenth century", History of Education, Vol. 41, No. 6, 2012, s.733-748.

14 İzcilik ve okul gezileri askerî eğitime hazırlık olarak düşünüldüyse de sanayileşme sonucu artan hava kirliği, hastalıklar ve gürültüden öğrencileri bir nebze de olsa kurtarmak, onları sakin sessiz yerlere çıarmak ve doğa ile yakın temas kurmalarını sağlamak amacına da matuftu.

15 John Horne (ed.), State, Society and Mobilization in Europe during the First World War, Cambridge University Press, Cambridge 1997, s.53-69; Dichter, age, s.787-806.

16 L. Thompson, "Militarism and Scottish schools in the Boer war era", Physical Education Review, 8, 2, (1986), s. 110-19.

17 Stolk, Los, age. 
ponya, Avustralya ve Yeni Zelanda'da ${ }^{18}$ militarist eğitim uygulamaları görülür. 1911'den itibaren Avustralya'da 12-26 yaş aralığındaki bütün erkeklerin askerî eğitim almaları öngörülüyordu. Almanya'da çok daha militarist bir eğitim vardı. II. Dünya Savaşı sonrasında müttefikler Alman eğitim sistemini düzenlemeye başladıklarında tam askerî bir içerikle karşılaşmışlardı. ${ }^{19}$ Avrupa ülkelerinde devlet okullarının yanında okul dışı kurumlar izcilik, genç dernekleri vb. yapilanmalarla toplumu askere hazırlama faaliyetleri yapıliyordu. Hollanda, Finlandiya ve İsveç'te bu türden pek çok paramiliter örgüt vardı, ancak bunlar gönüllï̈ ${ }^{20}$ kuruluşlard.

20. yüzyılın ilk çeyreğinde, Osmanlı Devleti ulus-devlete dönüşürken Avrupa'daki gelişmelere paralel tecrübeler yaşadı. Osmanlı eğitimi modernleşirken Avrupa'ya benzer uygulamalar başlanmış ve bazı okullar beden eğitim dersini programlarına koymuştu. I. Dünya Savaşı öncesinde de sırf askerî nedenlerde militarist uygulamalar ve paramilitarist örgütler çoğalmıştı. Bu örgütlerin çoğu hükümet tarafindan destekleniyordu ancak toplumun tamamını kapsamıyordu. Buna karşın, 1926 ve sonrasında orta ve yükseköğretimin bütün kademelerine konulan Askerliğe Hazırlık Dersi dünyada pek örneği görülen cinsten değildi. Dersin adı 1947'de değiştirildi, kamp ve pratik eğitim mecburiyeti kaldırıldı, haftalık saati azaltıldı, ancak içerik ve zihniyet değiştirilmeden 2012'ye kadar geldi. Bu anlamda 1926, Türk eğitim tarihinde aşırı militarist uygulamalar için bir kırılma noktası sayılabilir.

Türk eğitim sisteminin militarist cephesini tarihsel derinliği içinde inceleyen çok az araştırma vardır Bunlar arasında en önemli olan Altınay'ın tezidir. ${ }^{21} \mathrm{Bu}$ makale söz konusu dersin programa konulmasından 1947'deki dönüşümüne kadar olan süreci incelenmektedir. Araştırmanın temel kaynağ 1926 'da kurulan, Türkiyede eğitim programlarını hazırlayan ve eğitim sisteminin beyni sayılan Talim Terbiye Dairesi kararları ve bu kurum tarafindan yayımlanan Tebliğler Dergisidir.

\section{Osmanlı Son Dönemi Eğitiminde Beden Eğitimi ve Paramilitarizm}

Türkiye Cumhuriyeti Osmanlı devletinden pek çok kurum ve uygulamayı miras ald. Kamu eğitiminin benimsenmesi ve modern bir programa kavuş-

18 David Kırk ve Karen Twigg, "The militarization of school physical training in Australia: the rise and demise of the junior cadet training scheme, 1911-31", History of Education, 1993, Vol. 22, No.4, s.391-414.

19 Dichter, age, s.787.

20 Merja Paksuniemi, "mobilising children for national defence: Boys' Education in the finnish civil guard organisation during the Second World War", Childhood in the Past, 9, No. 1 2016, s. 44-57.

21 Ayşe Gül Altınay, The Myth of Military Nation: Militarism, Gender and Education in Turkey, Palgrave Macmillan, New York 2004. 
ması 1850'lerden itibaren başladı. Cumhuriyet dönemi zorunlu devlet eğitiminin merkezî, seküler, karma ve ideolojik kökenleri bu tarihlerde başlar. 1869 'da yayımlanan eğitim kanununa göre, bazı okulların programında beden eğitimi ve jimnastik vard. ${ }^{22}$ II. Abdülhamit döneminde Osmanlı ordusuna davet edilen Alman General Goltz "ordu-millet" mitini Türkiye'ye getiren kişi oldu. Zorunlu askerlik ve toplumun askerî ihtiyaçlar doğrultusunda topyekûn savaşa ve seferberliğe hazırlanması ihtiyacını anlatan ünlü eseri Das Volk in Waffen Almanca baskısından bir yıl sonra 1885'te Türkçeye çevrildi ve Harbiye'de ders kitabı olarak okutuldu. ${ }^{23}$

Mayıs 1914'te İngiliz Harold Parfitt Osmanlı'da izci derneklerini kurmak için Belçika'dan davet edildi ve izcilik Osmanlı okullarında başladı. 1914'ten itibaren toplumun seferberliğe hazırlanması için hükûmet kontrolünde "güç, genç ve gürbüz" adında ülkenin her tarafında yaygın faaliyetleri olan paramiliter örgütler kuruldu..$^{24} \mathrm{Bu}$ örgütlere okullu olmayan tamamıla gönüllülük esasına dayalı gençler katılıyor ve beden terbiyesi aracılığıyla sağlıklı asker yetiştirilmesi amaçlanıyordu. ${ }^{25}$ Paramiliter gençlik örgütleri 1914 sonrasında Harbiye Nezâreti kontrolüne geçti ve örgütlerin modern okullar yanında medreselerde de yaygınlaştırılması istendi. Güç derneklerinin idealine göre "bundan sonra herkes asker" olacak ve "vatan tehlikeye düştüğünde müdafaaya koşacaklardı." ${ }^{26}$ Osmanlı Genç ve Dinç Dernekleri, İttihat ve Terakki hükümetinin sivil milis gücü olarak askerliğine çok az kalmış gençlerin katıldığı ve bir tür askere hazırlık örgütüydü. Güç derneklerine okullu olmayan 12-20 yaş arası bütün erkeklerin katılması mecburdu ama katılmayanlar için belirgin müeyyidelerin olmaması nedeniyle örgütler yaygın ve etkili olamad. Örgütlerin asıl başarısızlık nedeni, hedef kitlenin gönülsüzlüğü idi, hatta bilinçli dirençler bile vardı. Bu örgütler 1914 sonrası savaşın ortaya koyduğu pratik ihtiyaçtan kaynaklanıyordu, savaş şartlarında ortaya çıkmıştı ve askerî eğitim herkese zorunlu değildi.

1926 sonrasının aşırı militarist unsurlarının Osmanlı dönemindeki diğer öncülü ise II. Meşrutiyet Dönemi (1908-1920) resmi okullarında uygula-

22 Selçuk Akşin Somel, The Modernization of Public Education in the Ottoman Empire, 1839-1908: Islamization, Autocracy and Discipline, Brill, Leiden 2001, ekler. 4, 5, 6, 7.

23 Colmar Freiherr von der Goltz, Millet-i Müsellaha: Asrımızın Usul ve Ahval-i Askeriyesi, (Çev.: Mehmed Tahir), İstanbul: Matbaa-i Ebüzziya, 1305/1888.

24 Bu tür yapılanmalar Almanya, İtalya, İngiltere, Hollanda, Finlandiya gibi ülkelerde de vardı bk.: Andrew C. Donson, War Pedagogy and Youth Culture: Nationalism and Authority in Germany in the First World War, unpublished PhD, The University of Michigan, 2000; Andrea Fava, "War, 'National Education' and the Italian Primary School, 1915-1918.

25 Türk Gücü Umumî Nizâmı, Türkün Gücü Her Şeye Yeter, Matbaa-i Hayriye, İstanbul 1329/1913, s.3.

26 Sadık Sarısaman, "Birinci Dünya Savaşı sırasında ihtiyat kuvveti olarak kurulan Osmanlı genç dernekleri”, OTAM, 2003, S.11. s.442. 
nan beden eğitimi dersleri, okul oyunları ve resmî bayram kutlamalarıdıd. 1912-1914 yılları arasında kız ve erkek lise programlarında beden eğitimi her sınıfta ikişer saate çıkarılmıştı. 1913'te hazırlanan ilköğretim programında beden eğitimi ve okul oyunlarından başka erkek çocuklar için "askerî eğitim" dersi [etfal-i zükûra talim-i askerî] konmuştu. ${ }^{27}$ İlk ve ortaöğretimdeki "hücum emri, sancak kapma, esir almaca" adındaki oyunlar tamamıyla militer karakterdeydi. Bu derslerde temel askerî bilgilerin yanında ölme ve öldürmenin mantığ 1 gençlere anlatılacak, bu sayede hem askerlik süresinden tasarruf edilecek hem de askerler daha nitelikli bir şekilde yetiştirilebilecekti. Askerî okul olmakla birlikte sivil alanı da ilgilendiren "endaht mektepleri" ${ }^{28}$ militarist eğitimin yaygınlaşmasına hizmet etti.

1916'da ilk defa Selim Sırrı Bey'in öncülüğünde Kadıköy'de "İdman Bayramı" düzenlendi. ${ }^{29}$ Aynı sene, Yüksek Öğretmen okulunda teorik ve uygulamalı derslerin yapılacağı Beden Eğitimi öğretmeni yetiştirmek için bölüm açıldı. Öğrenciler senede bir kere olsun resmî poligonlara götürülerek askerî talimleri andıran eğitim yapıyorlard $1 .^{30}$ İdman bayramlarına hazırlık tam bir askerî disiplin içinde gerçekleşiyordu ve bu uygulama Cumhuriyet döneminde de aynen devam etti.

\section{Eğitimde Aşırı Militarizmin Başlaması: Askerliğe Hazırlk Dersi, 1926.}

Osmanlının son döneminde kurulan paramiliter gençlik örgütleri 1920'ye kadar faaliyetlerini devam ettirdi. Bu dönemde beden eğitimi derslerinin içeriği de yoğun askerî görünüm altındaydı. 1923'te Cumhuriyet'in ilanından sonra eğitim sisteminin teşkilat ve felsefi yapısının reorganizasyonu için bir dizi reform yapildi. Avrupa ve Amerika'dan uzmanlar davet edildi. 1923'te yapılan kapsamlı eğitim kongresinde sağlıklı nesiller için "beden terbiyesi" ve "izciliğe" vurgu yapılırken ilköğretim öğrencilerini askerliğe özendirici şiir, marş, oyun ve gösterilerin derslerde yer alması tavsiye edildi. İzciliğin yaygınlaştırılmak istenmesinin sebeplerinden biri "ahlâkî ilkelerin etkin hale gelmesini sağlamaktı.”’1 $\mathrm{Bu}$ dönemde, Osmanlı son dönemi eğitimindeki "vatandaşlık bilgileri" (malumât-1 vataniye) ortaokul ve liselerde yaygınlaş-

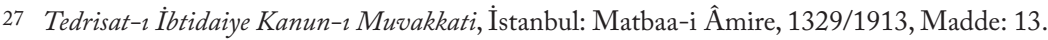

28 Mustafa Ergün, II. Meşrutiyet Devrinde Eğitim Hareketleri (1908-1914), Ocak Yayınları, Ankara 1996, s.305-309.

29 Selim Sırrı Tarcan, Hatıralarım, Türkiye Yayınevi, İstanbul 1946, s.55.

30 Maarif-i Umumiye Nezareti, Mekâtib-i İbtidaiye Ders Programı, Altı, Beş, Dört ve Ü̧̧ Dershaneli ve Muallimli Mekteplere Mahsus, Matbaa-i Amire, İstanbul 1330, s.108-110.

31 Osman Ergin, Türk Maarif Taribi, C.5, Eser Matbaası, İstanbul 1977, s.1722. 
tırıld.$^{32} \mathrm{Bu}$ dersin içeriğinde en çok vurgulanan kavram vatan, millî birlik, askerlik, vatana karşı görevler idi. Vatandaşlık ders kitaplarında askerliğin, millî birlik ve bütünlüğün muhafazası ve hürriyet için 'en birinci ve kutsal vazife $^{\prime 33}$ ve askerlikten kaçmanın 'vatana hiyanet ${ }^{34}$ olduğunu belirten ifadeler sıkça görülüyordu.

1924'te ortaöğretim, 1926'da da Maarif Teşkilatı ve İlköğretim kanunları ç1karılarak, Türk eğitim sistemi program, personel ve yapı bakımından yeniden düzenlendi. "1924 ilkokul programında beden eğitimi dersleri, silahla atış yapmayı da içeren bir çeşit "askerliğe hazırlık" dersi görünümündeydi. Kâzım Karabekir, Şubat 1925'te Maarif Vekâleti bütçesi görüşülürken 'artık milleti müselleha devrinin geldiğini kabul etmek gerekir' dedikten sonra beden eğitimi derslerinin daha ciddiyetle işlenmesini, silahla atış talimleri yapılmasına önem verilmesini istemişti. ${ }^{35} 22$ Eylül 1926 da eğitim programı politikacıları, liselerin erkek kısımları ve erkek öğretmen okullarının son iki sınıfına "askerî tedrisat ve talimler" konulu dersin konulmasını kararlaştırdı ve kararname Başbakan İsmet İnönü ve Cumhurbaşkanı Mustafa Kemal tarafından onaylanarak yayımland $1 .{ }^{36} \mathrm{Bu}$ dersin en karakteristik özelliği, en az yüzbaşı rütbesinde bir subay tarafindan verilecek olması ve 15 günlük uygulamalı kamp eğitimini öngörmesiydi. ${ }^{37}$

Hazırlanan talimatnameye göre, "askerî tedrisat ve talim" konularılla ilgili, liselerde Coğrafya, Tarih, Vatandaşlık ve Beden Eğitimi derslerinde topoğrafya, harita, arazi bilgisi, Türklerin tarihteki büyük savaşları, askerlik teşkilatı, askerliğe uygun bedensel hareketler gibi konu başlıklarının eklenmesi istenmiştir. Bu konular sivil öğretmenler tarafindan öğretilecekti, ancak konuların hakkıyla anlatılabilmesi için kitap, rehber vb. yardımcı materyal Genelkurmay tarafindan acilen hazırlanıp okullara gönderilecekti. Bunun d1şında Maarif Vekâleti'ne bağlı bütün erkek liseleri ve erkek öğretmen okullarına on beş günde bir "askerlik eğitimi" konferansı verilecekti. Program, Milli Talim ve Terbiye Dairesi ve Genelkurmay tarafindan birlikte hazırlanacak ve konferans Genelkurmay'ın tayin edeceği yüzbaşı rütbesindeki subaylarca verilecekti.

\footnotetext{
Hasan Âli Yücel, Türkiye’de Orta Öğretim, Kültür Bakanlığı Yayınları, Ankara 1994.

M. Sadullah Sander, Yeni Yurt Bilgisi: Sinıf III, Resimli Ay, İstanbul 1935-1936, s.80-81.

Abdülbaki [Gölpınarlı], Yurt Bilgisi, Türk Neşriyat Yurdu, İstanbul 1927-28 s.70.

5 Hasan Ünder, Kemalizmin Işı̆̆ında, Atatürk Döneminde Eğitsel Değerler, Ankara Üniversitesi, Eğitim Bilimleri Enstitüsü, Yayımlanmamı̧̧ Doktora Tezi, 1998, s.96.

36 “Kararname sureti”, Maarif Vekâleti Tebliğler Mecmuası, 10 Teşrin-i Sani 1926, S.10. s.7.

37 "Erkek lise sınıflarıyla erkek muallim mekteplerinin son iki sınıflarında yapılacak askeri tedrisat ve talimler hakkında talimatname”, Maarif Vekâleti Tebliğler Mecmuası, 10 Teşrin-i Sani 1926, S.10. s.8-10.
} 
Liselerle, ortaokul ve erkek öğretmen okullarında okutturulmak üzere, 1926'nın başında Genelkurmay Eğitim Dairesi tarafından bir kitap ${ }^{38}$ hazırlanmış ve okullara dağıtılmıştır. Kitabın her yeni baskısı, Tebliğler Dergisinde duyurulmuştur. Buradan anlaşıldığına göre, dersin okutulmasını Maarif Vekâletinden ziyade Genelkurmay tarafindan istenmekte ve önemsenmektedir. 1927 başında Maarif Vekili Mustafa Necati imzasıyla duyurulan habere göre ${ }^{39}$ Coğrafya, Tarih ve Vatandaşlik derslerine askerlikle ilgili yeni konular eklenmiş ve askerlik ders kitabı bütün okullara dağıtılmıştır. Bu yıldan sonra yazışmalarda ve okul programlarında dersin adı "Askerliğe Hazırlık" olarak yer almıştır.

1926'da başlayan "askerî tedrisat" ilk başta hem geniş öğrenci kitlelerini ilgilendirmiyor hem de şartları çok ağır değildi. Ancak bu uygulama giderek daha geniş öğrenci kesimini kapsayacak ve şartları ağırlaşacaktır. 1926'da kız ve erkek öğrencilerin selam vermesi, ${ }^{40}$ kasket ve bere giymeleri, ${ }^{41}$ toplu yürüyüş, bayram kutlamaları vb. konularında Talim Terbiye Kurulu bir dizi karar aldı. Bu kararlarda tanımlanan selam verme biçimleri tam anlamıyla askerî idi. Örneğin, öğrenci bir devlet büyügüne, okul müdürüne ya da öğretmenine selam vereceğinde topuklarını birleştirir, sağ el parmaklarını sıkıca bitiştirerek kasketine bitişik halde kaldırır ve daha sonra süratle indirir (talimatname No: 3). Öğrenciler selam verirken hata yapmamaları konusunda sürekli uyarıl1yorlard. Böylece askerî ritüeller okul kültürü haline getirilmeye çalış1lıyordu.

1926 Talimatnamesine göre (madde 5-15) öğrenciler 1-15 Ağustos arasında açık alanda kampa gidecekler ve her gün askerî eğitim yapacaklardı. Bu eğitimin nasıl yapılacağı hakkında farklı kişilerce kitaplar yazıldı. Kamplara hazırlık okulun bulunduğu bölgedeki garnizonla iş birliği içinde gerçekleşecekti ve bu süreçte idarî sorumluluk okul müdürlerine aitti..$^{42}$ Öğrencilerin kampa katılmalarında beden eğitimi öğretmeni öncelikli sorumluydu. Kamplar okula, her hangi bir araçla azami sekiz saat uzaklıkta ve çevre şartları eğitim ve sağlığa uygun olmalıydı. Genelkurmay'dan gelen subaylar yalnızca eğitimden mesuldüler. Kamplarda kullanılacak olan her nevi askerî teçhizat (askerî elbise, çadır, tüfek, fişek, nakil araçları...) okula en yakın askerî karargâh tarafından temin edilecekti. 1927'de askerî kamplara katılacak öğrenci ve öğretmen-

38 Cemil Tahir, Askerliğe Hazırlık Dersleri I, İstanbul: Harbiye Mektebi Matbaası, 1926.

39 Maarif Vekâleti Tebliğler Mecmuası, 15 Kanun-1 Sani 1926, S.12, s.18-20.

40 Maarif Vekâleti Tebliğler Mecmuası, 15 Mayıs 1926, S.4, s.37, Karar No: 9264/27; "Mektep talebesinin resmi selamı ne surette ifa edeceğine dair talimatname", Maarif Vekâleti Tebliğler Mecmuası, 15 Temmuz 1926, S.6, s.21.

41 "Kasket veya bere giyen mektep talebelerinin resmî selamı ne suretle ifa edeceğine dair talimat", $M a$ arif Vekâleti Tebliğler Mecmuası, 15 Mayıs 1926, S.4 s.19.

42 Maarif Vekâleti Tebliğler Mecmuast, 15 Ağustos 1926, S.7, s.9. 
lerin iaşe ve ibatelerinin aksamaması için kanun ${ }^{43}$ çıkarıldı. Tatil için başka yerlere giden öğrenciler, bulundukları yere en yakın lisenin kampına dâhil olabilirlerdi. Mazeretsiz kampa katılmayan öğrencinin "tavır ve hareket" notu yarı yarıya düşürülecekti. Ancak bu notun şimdilik sınıf geçme ve mezuniyete etkisi yoktu. Öğrenci, sağlık sebebiyle kampa katılamayacaksa doktor tarafından belgelenecekti.

Kampta tam askerî bir hava hâkimdi. Normal şartlarda bir kışlada hangi eğitimler yapılıyorsa okul kampında da aynısı vardı. Askerî eğitimde öğrenilecek hareketler ve kullanılacak silahlarla ilgili her türlü ayrıntı yönetmelikte belirtilmişti. Kamp programı bütün ayrıntılarıyla (silahların markasına varıncaya kadar) ${ }^{44}$ dönem başında yayımlanıyor ve her okula yardımcı materyalleriyle birlikte gönderiliyordu. ${ }^{45}$

Kamp eğitiminin bitiminde görevli subay, okul müdürü ve beden eğitimi öğretmeninin ortak bir rapor hazırlaması ve hem Genelkurmay'a hem de Maarif Vekâleti'ne göndermesi isteniyordu. Rapor tutmak üzere ilerleyen yıllarda bağımsız müfettişler de görevlendirilmiştir. Kamptaki eğitimi başarıyla bitiren öğrencilere subay ve okul müdürünün birlikte imzaladığ1 "ehliyetname" verilecekti. 1926'dan itibaren belge almak için sadece kampa katılmak yeterli iken 1936 sonrasında teorik (yazılı / sözlü) ve pratik sınavlar da getirildi. ${ }^{46}$ İlerleyen yıllarda bu belgenin türleri ve ne işe yarayacağı da detaylandırıldı. ${ }^{47}$ Buna göre, "orta, tam ve yüksek" olmak üzere üç tür ehliyetname vardı. Ortaokuldaki askerlik dersini alanlar orta, lisedeki dersleri alanlar tam, üniversitedeki askerlik eğitimine katılanlar da yüksek ehliyetname alabiliyorlard.. Ehliyet almak için illa öğrenci olmak gerekmiyordu, mezunlar da okul müdürlerine başvurarak belge alabilirlerdi. Askerlik öncesinde alınan ehliyetname, askere alınma sürecinde ibraz edilir ve sahiplerine farklı avantajlar sağlardı.

1927-28 öğretim yılı başında Askerliğe Hazırlık dersiyle ilgili sıkı gelişmeler görülür. Öncelikle yeni bir Askerlik Mükellefiyeti Kanunu ${ }^{48}$ çıarıldı. Ardın-

43 "Kamplara iştirak edecek talebe ve muallimlerin iaşesi hakkında kanun”, Resmi Gazete, 28.05.1927, Kanun No: 1024.

44 “Askere hazırlık tedrisatı talimatnamesine ilave”, Maarif Vekâleti Tebliğler Mecmuası, 15 Kanun-1 Sani 1927, S.21-24, s.123.

45 Maarif Vekâleti, Tebliğler Mecmuası, 15 Mart 1927, S.14, s.14-15 ve 15 Haziran 1927, S.17.

46 "Orta, lise ve ilköğretim okulları askerlik dersi sınav talimatnamesi”, Milli Talim ve Terbiye Dairesi, Karar No: 57, 02.06.1936.

47 Askerliğe Hazırlık Tedrisatı, Askerî Ebliyetname Almak ve İbtiyat Zabiti Hazırlık Kıtaları Hakkında Talimatname, Erkân-1 Harbiye-i Umumiye Matbaası, Ankara 1927.

48 Askerlik Mükellefyeti Kanunu, İstanbul: Orhaniye Matbaası, 1928; Resmi Gazete, 12 Temmuz 1927, S. 631. 
dan, Askerlik ve İhtiyat Zabiti Kanunu ${ }^{49}$ ile yedek subaylığa (ve genel olarak askerliğe) hazırlık sürecinin, "askerî ehliyetname" adıla sivil okul sistemine bağlanması gündeme geldi. Alınan bu karar ve talimatnamenin içeriği, sivil okullara entegre edilmiş askeri ehliyetname uygulamasının, Cumhuriyet öncesi militarist beden eğitimi perspektifiyle okul çağındaki gençlerin askerliğe sürekli hazır tutulmasını hedefleyen araçlar olarak İzcilik, Güç dernekleri ve özellikle I. Dünya Savaşı yıllarında yaygınlaşan Genç Dernekleri deneyimiyle benzerlik göstermekteydi. 1927'de askerlik dersinin liselerin yanında ortaokullara, ticaret ve sanat liselerinde okutulması istenmişse de $\mathrm{e}^{50} 1932$ 'ye kadar gerçekleşmediği anlaşılmaktadır. Bu sıralarda Beden Eğitimi derslerine gereken önemin verilmediğinden bahisle, ${ }^{51}$ askerî talimlere gereken önemin verilmesi uyarisi yapiliyordu.

1928 başında Genelkurmay Başkanı Fevzi [Çakmak] imzalı gönderilen ve bütün okullara dağıttılması istenen tamimde, ${ }^{52}$ askerlik dersinin işlenişiyle ilgili ciddî uyarılarda bulunulmaktadır. Yazıda Genelkurmay, askerî eğitimde bazı eksiklerin olduğunu belirtir ve böylesi bir eğitime yeni başlandığını, yanlışlı̆̆a mahal vermemek için azami dikkat gösterilmesi gerektiğini ve daima kendileriyle irtibat halinde olunmasını istemiştir. Ders veren subayların maaşını Maarif Vekâleti'nden alması gerektiği ama bu konuda aksamaların olduğu, aslında ücretin teşvik amaçlı olup, zabitlerin bu dersi yüksek bir vazife telakki ederek vermeleri gerektiği belirtilmiştir. Ders ücretlerini arttırma talebinin ise anlamlı olmadığına ayrıca değinilmiştir. Dersler işlenirken hiçbir konunun atlanmaması, gönderilen kitaplara ve talimatnamelere ciddiyetle uyulması, her üç ayda bir ve kamp bitiminde kapsamlı rapor hazırlanarak gönderilmesi istenmiştir. Askerlik dersi kamplarında, talebeye rahat spor k1yafetlerin giydirilmesi, tek-tip kıyafete mecbur edilmemeleri de istenmiş ve burada Avrupa örnek gösterilerek, biz onlardan daha ilerideyiz mesajı verilmiştir. ${ }^{53}$ Ayrıca ilgili dersin teftişlerinin daha sıkı yapılması istenmiştir.

\section{Ordu-Millet Düzleminde Tarih ve Eğitim}

1931'de Türk Tarih Kurumu, bir sene sonra da Türk Dil Kurumu kurularak yeni devletin ideolojik ve kültürel reformları radikal bir ivme kazand.

\footnotetext{
49 "İhtiyat Zâbitleri ve İhtiyat Askeri Memurları Kanunu”, 16 Haziran 1927, Düstûr, III. Tertip, C. 8, s.733-744.

50 "Askerliğe hazırlık derslerinin orta mekteplere de şamil olduğu hakkında”, Maarif Vekâleti Tebliğler Mecmuasi, 15 Kanun-1 Sani 1927, S.21-24, s.121 ve s.130.

51 Maarif Vekâleti Tebliğler Mecmuası, 15 Kanun-1 Sani 1926, S.12, s.26.

52 “Askerî Tedrisat Hakkında”, Maarif Vekâleti Tebliğler Mecmuası, 15 Mart 1928, S.25-26, s.56-57.

53 “Askerî Tedrisat Hakkında”, s.61.
} 
19. yüzyıl sonu bilim paradigması doğrultusunda antropolojik ve folklorik araştırmalarla desteklenen yeni kimlik, kültür ve millet inşasında, Türklerin millet olarak asker olduklarına vurgu yapıld. ${ }^{54}$ Liseler için hazırlanan yeni Tarih kitabında "Türkçülük ve askerlik hizmeti”ne ayrı bir bölüm ayrıldı ve Türklerin aslen asker olduklarını ve taşıdıkları kültürel kodlar ve "askerî ruh" sebebiyle dünyanın en iyi askerleri oldukları iddia edildi. ${ }^{55}$

Liselerde okutulmak üzere, Mustafa Kemal'den belirgin izler taşımakla birlikte Âfetinan ve Recep Peker tarafından hazırlanıp 'Afet' imzasıyla yayımlanan Medenî Bilgiler kitabında "asker millet” temasına güçlü vurgu yapıldı. Asker ocağını, "milletin yetişmiş gençlerini yalnız askerlik nokta-i nazarından değil, irfan nokta-i nazarından da tedris ve talim eden bir mektep ve terbiye ocağ ${ }^{56}$ olarak tanımlayan kitaba göre, askerlik sadece kışlaya has değil, bütün okulları da kapsamalıydı. Bir anlamda bütün okullar kışlanın bir parçası olmalıydı. Çünkü "zamanımızda askerlik maddî, fikrî, o kadar çok kabiliyet istemektedir ki hazarda silahaltında geçirilecek az zamanda bunların elde edilmesi güçtür. Bunun için, vatandaşların henüz mekteplerde iken askerlik hizmetini kolaylaştıracak bir takım şeyleri öğrenmeleri, idman etmeleri lazımdır. Millî his, vatan muhabbeti ve devlet fikri ise vatandaşların ana kucağından, aile ocağından başlayarak alacakları en esaslı terbiye ve bilgilerdir. ${ }^{57}$ Zorunlu askerliğe "özel bir ciddiyet, ulviyet ve kutsallık atfeden kitap, II. Abdülhamit döneminde Türkçeye çevrilen Goltz'un eserinden sadece etkilenmekle kalmamış, bazı kısımlarını bizzat ondan” kopyalamıştı.

Medenî Bilgiler' in parçası olarak hazırlanan Askerlik Vazifesi başlıklı kitapçı, ${ }^{58}$ Başvekil İsmet Bey ve Genelkurmay Başkanı Fevzi Paşa'nın onayıyla kamuoyuna takdim edilirken Goltz Paşa’nın tüm ülkeyi bir ordugâh olarak gören, ordunun millete değil, milletin orduya hizmet etmesini esas alan 'ordu-millet' doktrinini güçlü bir şekilde popülerleştiriyordu. Kitapta, "kutsal ordu” ima$\mathrm{j} 1$ altında ona itaat etmenin zaruretine vurgu yapılırken milleti aydınlatmak için okul ne ise, ordunun da aynı görevi yerine getirdiği belirtilir. Yazara göre ordu, eşitlik duygusunun kazanılacağ1, cesaret ve teşebbüs fikirlerinin geliştirileceği, vatandaş olma bilincinin kazanılacağı mekândır. Bir devletin güçlü ve yüksek medeniyete sahip olabilmesi için, yegâne koruyucusunun ordu olduğu, onun sayesinde diğer ülkelerin karşısına çıkılabileceği şart olarak sunu-

54 Başar Arı, "Religion and nation-building in the Turkish Republic: comparison of high school history textbooks of 1931-41 and of 1942-50", Turkish Studies, 14/2, 2013, s.372-393.

55 Türk Taribinin Ana Hatları I, Devlet Matbaası, İstanbul 1931, s.344.

56 A. Âfetinan, Medenî Bilgiler ve M. Kemal Atatürk'ün El Yazıları, Türk Tarih Kurumu, Ankara 1998, s.122.

57 A. Âfetinan, age, 1998, s.111, 115.

58 [Afet], Yurt Bilgisi Notlarımdan, Askerlik Vazifesi, Devlet Matbaası, İstanbul 1930. 
lur. Yazar bir millet için ana görevin, "ordunun mükemmeliyeti için çalışmak ve çocuklarını askerlik vazifesini fedakârlıkla yapabilecek yüksek his ve kabiliyette yetiştirmek" ${ }^{59}$ olduğunu belirtir.

\section{Topyekûn Asker-Millet Yetiştirme ve Okulların Kışlalaştırılması}

Genelkurmay 1927'deki isteğini 1931'de tekrarlayarak Askerlik Dersi'nin ortaokullarda okutulmasını yeniden istedi. Talim ve Terbiye Kurulu üyelerinden Ali Haydar (Taner) bu isteğe, "orta mekteplerle muallim mekteplerinin ikinci ve üçüncü sınıf talebelerinin yaşı küçüktür, dolayısıyla bu sınıflara Askerliğe Hazırlık dersi verilmesi taraftarı değilim" ${ }^{\prime 0}$ diyerek itiraz etmişse de başkan dâhil diğer dört üye Genelkurmay'ın isteğini onaylayarak bakanlığa göndermiştir. Bir yıl sonra meslekî okullarda Askerlik Dersi'nin iki saate çıkarılması istenmiş, programa uyacak şekilde yalnızca üç ve dördüncü sınıflara ikişer saat ders konulmuştur. ${ }^{61}$ Aynı yıl, Musiki Muallim Mektepleri'nin beşinci ve altıncı sınıflarına ikişer saat Askerlik Dersi konulmuştur. ${ }^{62}$

1935 'te Talim ve Terbiye Kurulu kararılya ${ }^{63}$ resmi ve özel bütün ortaokullarla liseler ve bunlara denk birinci derecedeki uzmanlık okullarının her sınıfiyla Devlet Konservatuvarı, Ticaret, Kaptan, Çarkçı, Makine, Ziraat okullarına haftada ikişer saat Askerlik Dersi konuldu. Üniversitelerle yüksek uzmanlık okulları, Gazi Terbiye Enstitüsü öğrencileri de bir öğrenim döneminde 180 saatlik Askerlik Dersìyle ödevli tutuldular. Daha önceden 15 gün olan kamp hayat1 20 güne çıkarıldı. Üniversitede sadece askerî eğitimin yapıldığı Darülfünun Talim Taburu oluşturuldu ve burada yedek subay hazırlığ 1 yapiliyordu. Aynı y1 Askerlik Dersi kamp yoklama yönetmeliği hazırlanarak ${ }^{64}$ derslere devam daha da ciddiye alındı. Ders ve sınıf geçme bakımından Askerliğe Hazırlık dersinin diğer derslerden farkının olmadı $\breve{g}_{1},{ }^{65}$ mezun olmak için bu dersin teorik ve pratik kısımlarından başarılı olma şartı getirildi.

Maarif Vekâleti askerlikle ilgili işleri özel olarak takip etmek ve Genelkurmay ile doğrudan iş birliğgi halinde çalışmak için 1937'de kanun ${ }^{66}$ uyarınca kendi bünyesinde bir Seferberlik Direktörlüğü kurdu. Direktörlük Vekâlete

\footnotetext{
59 [Afet], age, 1930, s.52.

60 Milli Talim ve Terbiye Dairesi, Karar No: 193, 2.12.1931.

61 Milli Talim ve Terbiye Dairesi, Karar No: 54, 24.9.1932.

62 Milli Talim ve Terbiye Dairesi, Karar No: 11, 19.1.1932.

63 Türkiye Cumburiyeti Maarifi, 1923-1943, Maarif Matbaas1, Ankara 1944, s.112.

64 “Askere Hazırlık Dersi Yoklaması”, Milli Talim ve Terbiye Dairesi, Karar no: 96, 02.05.1935.

65 “Ortaokullarla liseler ve öğretmen okulları askerlik dersleri sınavları talimatnamesi”, Kültür Bakanlı̆̆l, Kültür Kurulu, No: 57, 02.06.1936.

66 “Maarif Vekâleti Merkez ve Teşkilat Kanunu”, Resmi Gazete, 23.06.1937, Kanun no: 3225.
} 
bağlı bütün kurum ve okulların seferberlik işleri, hava ve gaz taarruzlarına karşı korunma tedbirleri, okullardaki Askerlik Dersleri'nin ve kampların geliştirilmesi ve öğretmenlerle öğrencilerin askerlik işlerinin koordinasyonuyla görevlendirilmişti. ${ }^{67}$ Bir sene sonra dünyada başka örneği olmayan, paramilitarizmle doğrudan ilgili daha geniş bir projeye başland $1 .{ }^{68}$ Çıkarılan Beden Eğitimi Kапиnu ile 12-45 yaş arası erkekler ile 12-30 yaş arası kızlar düzenli bir şekilde beden eğitimi yapmaya mecburdular. Bunun için okullara büyük bir bütçe ayrıldı ise de II. Dünya Savaşının çıkmasıyla proje hayata geçirilemedi.

Başlangıçta, Askerlik Dersi'yle kızların geri hizmetler için yetiştirilmesi düşünülmüşse de ${ }^{69} 1935$ 'ten sonra teorik ve pratik kısımlarıyla Askerlik Dersi kızlar için de mecburi hale getirildi. Kızlar da hafif ve ağır makinalı tüfeklerin başında atış talimleri yapacaklardı. Kızların Askerlik Dersi uygulamalarında bazı sorunlar vardı. En başta kı lise ve ortaokullarında ders verecek subay bulunamıyordu. Bunun için, erkek subayların kızlara ders verebileceği kararlaştırıldı. Kız ve erkek sınıflarının Beden Eğitimi ve Askerlik Dersleri’nin aynı saate denk getirilerek subayların bir günde her iki sınıfa da ders vermesi uygun görüldü. ${ }^{70}$ İkili öğretim yapan okulların programına bir saat Askerlik Dersi teknik olarak eklenemiyordu. Ancak kızlar için bu ders o kadar önemliydi ki ikinci ve üçüncü sınıflardaki üç saatlik biyoloji dersi iki saate düşürülerek Askerlik Dersi'nin eklenmesi kararlaştırıldı. 1940'ta da Kız Enstitüleri'nin üçüncü sınıfında, Biçki-Dikiş dersi bir saat azaltılarak yerine Askerlik Dersi kondu. ${ }^{71}$ Kızların kamp hayatında karşılaşacakları zorluklara karşı cesaretlendirici tebliğler yayımlanırken eğiticilere kızlara karşı daha şefkatli davranmaları da öğütleniyordu. Tam bu sırada, Atatürk'ün manevi kızı Sabiha Gökçen dünyanın ilk kadın savaş pilotu olarak kokpite oturduğunda Mustafa Kemal, "Seninle gurur duyuyorum Gökçen! Sadece ben değil, bu olayı dikkatle izleyen tüm Türk milleti de seninle gurur duyuyor (...) Biz asker milletiz. Yediden yetmişe, kadın ve erkek, bizler asker olarak yaratıldık!"72 diyerek onun şahsında bütün Türk kızlarını cesaretlendiriyor ve askerlik hizmetinde kadın erkek farkının olmadığını dile getiriyordu. 1941 Cumhuriyet Bayramı kutlamalarında, kız izci takımının askerî nizamda ge-

67 Maarif Vekâleti, Türkiye Cumburiyeti Maarif, 1923-1943, Ankara: Maarif Matbaas1, 1944, s.112-113.

68 Sait Tarakçığlu, "A Failed project in Turkey's sports history: the law on physical education of 1938”, The International Journal of the History of Sport, 2014, Vol. 31, No. 14, 1807-1819.

69 Türkiye Cumburiyeti Maarif, 1940-1941, İstanbul: Maarif Matbaas1, 1941, s.117.

70 "Bazı ortaokullarda kızlara mahsus askerlik dersleri hakkında”, Kültür Bakanlı̆̆ı, Kültür Kurulu, Karar no: 4, 11.01.1938.

71 Maarif Vekilliği Tebliğler Dergisi, 14 Birinciteşrin, 1940, S.92, s.46.

72 Sabiha Gökçen, Atatürk'le Bir Ömür, Oktay Verel’in Kaleminden, İstanbul: Altın Kitaplar, 1996, s.126. 
çiş yapması istenmişti. ${ }^{73}$ Bununla birlikte kızlar ${ }^{74}$ ve erkekler ${ }^{75}$ için ayrı $A s-$ kerlik Ders Kitapları okutuluyordu.

Bu dönemde "ordu tam bir okuldur, bu yüzden okullar da tam bir ordudur"76 diyen ders kitabı yazarına göre, okul, ordu ve gençlik sağlıklı bir toplum üçgenini oluşturuyordu. Artık "okulların kışlalaştırılması" 77 projesiyle milleti topyekûn savaşa hazır hale getirmek mümkün görünüyordu. Askerliğe Hazırlık Dersleri 1935 'ten 1945 'e kadar çok değişime uğramadan ancak bazı talimatnameler yenilenerek devam etti. CHP 1935 programında yeni gençlik örgütlerinin kurulmasını önermişti. Burada her kesim için zorunlu beden eğitim dersi öngörüldü. ${ }^{78} 1938$ 'de bütün toplum için "zorunlu beden eğitimi kanunu" getirilmiş, ancak II. Dünya Savaşı yüzünden uygulanamamışt1. ${ }^{79} 1940$ sonrasında eğitime başlayan Köy Enstitüleri'nin programında da iki saatlik Askerlik Dersi vardı. Dersi mümkün olan yerlerde subaylar, olmayan yerlerde de emekli subaylar ya da askerliğini yedek subay olarak yapan öğretmenler verecekti. ${ }^{80}$ Yine 1941'de liselerde açılan Klasik şubelerin (Ankara Erkek Lisesi, Galatasaray ve Vefa) programında ${ }^{81}$ da iki saatlik Askerlik Dersi vard. "Askerliğe Hazırlık Dersleri Yönetmeliği” 1945'te yenilendiyse ${ }^{82}$ de 1947'de yürürlükten kaldırılarak yerine "Milli Savunma Öğretimi Yönetmeliği”" kabul edildi. Buna göre "Milli Savunma" derslerinden artan ders saatleri yerine farklı dersler eklendi. ${ }^{83}$

\section{5. İçerik ve İdeolojinin Sürekliliği: Askerlik Dersi Yerine, Milli Güvenlik Dersi}

II. Dünya savaşı sonrasında Türk siyasal ve kültürel hayatında gönülsüzce de olsa, çok partili hayata geçiş, demokratikleşme, dinî hayatta liberal politikalar, Köy Enstitüleri'nin kapatılması vb. konularında radikal değişimlere gidildi. Tek parti döneminin önde gelen eğitim bürokratları görevlerinden alındı. Elbette savaş zamanının gereği olarak bütün okul kademelerinde teorik ve pra-

\footnotetext{
73 Maarif Vekilliği Tebliğler Dergisi, 14 Birinciteşrin, 1940, S.92, s.44.

74 Recai Ökten, Askerliğe Hazırlık, Kızlar İ̧̧in, Mf. Yayınları, Ankara 1941.

75 Hakkı Ezgeç, Askerliğge Hazırlık, Erkekler İçin, Mf. Yayınları, Ankara 1942.

76 Kadri Yaman, Yurt Müdafaasında Türk Gençliği, Devlet Matbaası, İstanbul 1937, s. 40.

77 Altınay, age, bölüm: 5, s.119.

78 CHP Programı, 1935, Madde: 50, s.43.

79 Tarakçıŏlu, age.

80 "Köy Enstitülerinin askerlik dersi öğretmenleri hakkında”, Maarif Vekilliği Tebliğler Dergisi, 5 Mayıs 1941, S. 119, s.164.

81 Maarif Vekilliği Tebliğler Dergisi, 12 Mayıs 1941, S. 120, s.166.

82 Talim ve Terbiye Dairesi, Karar no:3/3196, 01.10.1945.

83 “Talim Terbiye Dairesi Kurul Kararı”, 1947, zikreden: Nevzad Ayas, Türkiye Cumburiyeti Milli Eğitimi, Kuruluşlar ve Tariḩ̧eler, Milli Eğitim Basımevi, Ankara 1948, s.560.
} 
tik okutulan Askerlik Dersi bu değişimin dışında kalamazdı. Nitekim 1945-46 eğitim yılı başında Eğitim Bakanı Hasan Âli Yücel okullara gönderdiği ve öğretim yılının ilk saatinde öğrencilere okunmasını istediği genelgede "artık savaşın bittiğini, kansız ve ateşsiz terletici bir savaşın başladığını ve asıl bu savaşı kazanmak mecburiyetinde olduğumuzu" ${ }^{\prime 4}$ vurgulanmıştı. Bu meyanda ilk olarak 1946-47 öğretim yılı başında genel liseler ve ticaret liseleri hariç Askerlik Dersi ve 20 günlük yaz kampları programdan kaldırıldı ${ }^{85}$ yerine, iki saatlik Yurt Bilgisi ve Türk Ahlakının İlkeleri adlı dersler konuldu. Bu derslerin içeriğinde de askerî bilgiler çoktu. Askerlik dersi genel liselerde yine subaylar tarafindan teorik olarak haftada bir, bazen iki saat olarak okutulmaya devam etti. 1947'de Genelkurmay'ın da katılımıla “Milli Savunma Öğretimi Yönetmeliğgi”" hazırlandı. Bu yönetmeliğe göre, okullarda okutulacak her türlü milli savunmaya ilişkin dersin içeriği, teori ve uygulama programları Genelkurmay tarafından hazırlanacaktı. Liselerde okutulan Askerliğe Hazırlık Dersi'nin adı 1950'de Milli Güvenlik Bilgisi, ${ }^{87} 1960$ darbesinden sonra da Milli Savunma ve Milli Güvenlik Bilgisi olarak değiştirildi.

Askerlik Dersi farklı isimle verilmeye devam etmesine karşın, okutulan kitapların içeriğinde radikal değişiklikler yoktur. Askerliğin kutsallığ1 ve orduya itaat etmenin fazileti, zorunlu askerliğin erdemleri, vatan için can vermenin zarureti gibi konular kavram ve felsefe değişimi olmadan devam etti. Askerlik Dersinnin kaldırıldığı tarihe kadar değişmeyen kuralı, subaylar tarafından verilmesi ve Genelkurmay tarafindan kontrol edilmesi ve gerektiğinde program düzenlemesine ve değişimine gitmeleridir. 1950’ye kadar kız ve erkekler için ayrı kitap uygulaması da bu tarihten sonra kaldırıldı.

\section{Sonuç}

1926'dan beri Türk eğitim sisteminin farklı kademelerinde değişik isimlerle okutulmakta olan "Askerliğe Hazırlık ya da Milli Güvenlik" dersi 2012'de yürürlükten kaldırıldığında ${ }^{88}$ üzerine neredeyse hiç tartı̧̧ma yapılmadı. Oysa bir yıl sonra, 1933'ten beri ilköğretim öğrencilerinin her sabah askerî ritüelle okudukları “Öğrenci Andı” nın kaldırılmasına gösterilen tepki ve protestolar iki uygulamanın sembolik değer farkından kaynaklanıyordu. Aynı dönemde ilk ve orta-öğretimdeki tek-tip kıyafet uygulamasının devamını savunan geniş kesimler

\footnotetext{
4 Milli Eğitim Bakanlığı Tebliğler Dergisi, S.346, 17 Eylül 1945, s.279.

85 Milli Eğitim Bakanlı̆̆ı Tebliğler Dergisi, 29 Eylül 1947, S.453, s.87-88.

86 Talim ve Terbiye Dairesi, Karar no:1/5612, 05.05.1947.

87 Altınay, age, s.132-133.

88 Resmi Gazete, No. 28184, 25.01.2012.
} 
görüldü. Eğitim reformlarına gösterilen refleks, eğitim ritüellerinin toplumsal davranış ve zihinlerin biçimlenmesine olan derin etkisinden kaynaklanıyordu. Bir anlamda 1926-1950 arası aşırı militarist eğitim programları, ders kitapları ve okul kültürü 2000'li yılların antidemokratik zihinsel dünyasını hazırlamışıı.

Türkiye'de 1926 sonrasında yeni tarih, kültür ve eğitim reformlarılya inşa edilen ulus-devlet ve millet yapısı kendine özgü resmî akademik dünya yaratarak varlığını bu güne kadar sürdürdü. Öyle ki iki büyük savaş arası sosyo-psikolojik faktörüyle ders programlarına konulan ve sıkıca uygulanan askerlik derslerinin teorik zemininde, Türklerin asker-millet olduğu kabulü vardı. Oysa yukarıda değinildiği üzere bu algı, elli yıl kadar önce Alman Goltz Paşa’nın ürettiği bir doktrindi, ancak 1930 sonrası yetişen Türk tarihçileri bu algıyı neredeyse hiç sorgulamadan, tarihi bir hakikat olarak yaygınlaştırdılar. ${ }^{89}$ Içlerinde, tamamıyla modern eğitime geçiş sürecinin ürünü olan, 1869 sonrasında programa konulan, II. Meşrutiyet döneminde yaygınlaştırılan Beden Ĕ̈itimi ve Spor Dersini “Türklüğün millî ve tarihî bir geleneği” şeklinde sunanlar bile çıktı. Elbette bu yaygın algının tartışmaya değer pek çok yönü vardır. Ulusdevletin inşası amacıyla üretilen "asker-millet" metaforunu tartı̧̧ak ancak 1926 sonrası eğitim programlarının tahliliyle mümkündür.

Paramiliter gençlik örgütleri, beden eğitim dersleri ve zorunlu askerliğge hazırlık dersleri yeni ulus-devlet tasarımı altında resmî Türk milliyetçiliğinin eğitim ve ordu düzlemindeki özgün ifadesidir. Siyasal iktidar 1926'da muhalefeti tam anlamıyla sustururken seleflerinin eğitim projelerini değiştirmek yerine daha da güçlendirdiler. Osmanlı son dönemi eğitiminin daha gevşek militarist unsurları bu tarihten sonra katı bir şekilde uygulanmaya başladı. I. Dünya Savaşı yıllarında paramiliter gençlik örgütlerinin ve okullarda askerliğe hazırlık benzeri uygulamaların makul gerekçesi olabilirdi. Ancak 1926 sonrasında sıkı askerlik dersi uygulamalarının meşruiyetinden bahsetmek güçtür. Bunun açıklaması iktidar sahiplerinin kendi eğitim tecrübelerinde ve toplumsal mühendislik tasarımlarında aranabilir.

Cumhuriyet büyük ölçüde Osmanlı son dönemi modern askerî okullarında yetişen üst rütbeli subay ve bürokratların iş birliğiyle kuruldu. Devleti kuran kadronun yegâne sermayesi II. Abdülhamit döneminde açılmış modern askerî okullarda aldıkları eğitimdi. Bu kadro, yeni devletin eğitim sistemini ve geleceğin toplumunu tasarlarken kişisel tecrübelerine ve zamanın hâkim toplumsal tezlerine müracaat edeceklerdi.

Siyasetin, eğitim bürokrasisinin ve program yapıcılarının başında asker kökenliler vardı. Bu bakımdan eğitimin içeriğinin askerî zihniyet ve ritüeller-

89 Ayas, age, s.550. 
de doldurulması kimseyi rahatsız etmiyordu. Bu sebeple gittikçe aşırılaşan askerî eğitim uygulaması, 1950’lere gelindiğinde yaygın bir kabule kavuştu ve bir anlamda militer eğitim kadın erkek, bütün kesimlerce içselleştirildi. Bu tutum, Türkiye'de ordunun daima en ön planda olmasinı, her türlü sorunu çözüme kavuşturacak siyaset üstü aşkın bir yapıya dönüşmesine sebep oldu.

Türkiye, 1945 sonrası yeni düzende yerini alabilmesi için siyasî, askerî, ekonomik ve eğitim kurumlarında Amerika'nın isteği ekseninde değişimlere gitti ve eğitim programları yeniden yapilandırıldı. 1940'ta kurulan ve Sovyet etkileri gözlenen Köy Enstitüleri köklü biçimde değiştirildi. Truman Doktrini ve Marshall Planı doğrultusunda eğitim yardımları alındı, Amerikalı eğitim uzmanları Türkiye'ye geldi ve yeni eğitim komisyonlarıyla müfredat değiştirildi. 1946 sonrasında eğitim programındaki aşırı militarist vurgunun değişmesinde bu gelişmeler etkili oldu.

Askerlik derslerinin eğitim programına konulmasından, uygulanmasına, değerlendirilmesine varıncaya kadar en etkin kurum Genelkurmay olmuştur. Derslerin içeriği ve işlenişini subaylar takip etmiştir. Bürokratik olarak Savunma Bakanlı̆̆ı'na bağlı olan Genelkurmayın, dengi olmayan Eğitim Bakanlığına sürekli emirler göndermesi, ordunun Türk siyasal ve bürokratik hayatındaki etkisini ve üstünlüğünü göstermesi bakımından da önemlidir. Genelkurmayın eğitim sistemine üstünlük kurma çabası, askerlik dersleri yoluyla 1950’lere kadar pekişmiştir. Bugün Türk eğitim sisteminde, her ne kadar ritüel düzeyinde bir çok askerî uygulama temizleniyor olsa da kavramsal ve felsefî düzlemde 1926-1947 arasında zihinlere nakşedilen doktrin varlığını canlı biçimde sürdürmektedir.

\section{Kaynaklar}

\section{Arşiv ve birincil kaynaklar:}

"Askere hazırlık tedrisatı talimatnamesine ilave" (15 Kanun-1 Sani 1927). Maarif Vekâleti Tebliğler Mecmuası, s.21-24.

"Askerî tedrisat hakkında" (15 Mart 1928). Maarif Vekâleti Tebliğler Mecmuası, s.25-26.

"Askerliğe hazırlık derslerinin orta mekteplere de şamil olduğu hakkında"(15 Kanun-1 Sani 1927). Maarif Vekâleti Tebliğler Mecmuası, s.21-24.

"Bazı ortaokullarda kızlara mahsus askerlik dersleri hakkında" (11.01.1938). Kültür Bakanlığ̆, Kültür Kurulu, Karar no: 4.

"Erkek lise sınıflarıyla erkek muallim mekteplerinin son iki sınıflarında yapılacak askeri tedrisat ve talimler hakkında talimatname" (10 Teşrin-i Sani 1926). Maarif Vekâleti Tebliğler Mecmuası, s.10. 
"İhtiyat zâbitleri ve ihtiyat askeri memurları kanunu" (16 Haziran 1927). Düstûr, III. Tertip, c.8, s.733-744.

"Kamplara iştirak edecek talebe ve muallimlerin iaşesi hakkında kanun" (28.05.1927). Resmi Gazete, Kanun no: 1024.

"Kararname sureti”(10 Teşrin-i Sani 1926). Maarif Vekâleti Tebliğler Mecmuast, s.10.

"Kasket veya bere giyen mektep talebelerinin resmî selamı ne suretle ifa edeceğine dair talimat" (15 Mayıs 1926). Maarif Vekâleti Tebliğler Mecmuast, , s. 4 .

"Köy Enstitülerinin askerlik dersi öğretmenleri hakkında” (5 Mayı 1941). Maarif Vekilliği Tebliğler Dergisi, s.119.

"Maarif Vekâleti merkez ve teşkilat kanunu"(23.06.1937). Resmi Gazete, Kanun no: 3225 .

"Mektep talebesinin resmi selamı ne surette ifa edeceğine dair talimatname" (15 Temmuz 1926). Maarif Vekâleti Tebliğler Mecmuası, s.6.

"Askere hazırlık dersi yoklaması"(02.05.1935). Milli Talim ve Terbiye Dairesi, Karar no: 96.

Askerliğe Hazırlık Tedrisatı, Askerî Ehliyetname Almak ve İhtiyat Zabiti Hazırlık Kıtaları Hakkında Talimatname (1927). Ankara: Erkân-1 Harbiye-i Umumiye Matbaasi.

Askerlik Mükellefiyeti Kanunu (12 Temmuz 1927). İstanbul: Orhaniye Matbaasi.

"Ortaokullarla liseler ve öğretmen okulları askerlik dersleri sınavları talimatnamesi” (02.06.1936.). Kültür Bakanlğğ, Kültür Kurulu no: 57.

"Orta, lise ve ilköğretim okulları askerlik dersi sınav talimatnamesi" (02.06.1936). Milli Talim ve Terbiye Dairesi, Karar no: 57.

Milli Ĕ̈̆itim Bakanlı̆̆̊ Tebliğler Dergisi (29 Eylül 1). 947, S.453.

Milli Ĕ̆gitim Bakanliğı Tebliğler Dergisi $(17$ Eylül 1945). S.346.

Milli Talim ve Terbiye Dairesi (19.1.1932). Karar no: 11.

Milli Talim ve Terbiye Dairesi (2.12.1931). Karar no: 193.

Milli Talim ve Terbiye Dairesi (24.9.1932). Karar no: 54.

Maarif Vekâleti Tebliğler Mecmuası (15 Ağustos 1926). S.7.

Maarif Vekâleti Tebliğler Mecmuası (15 Kanun-1 Sani 1926). S.12.

MaarifVekâleti Tebliğler Mecmuası (15 Kanun-1 Sani 19). 26, S.12.

Maarif Vekâleti Tebliğler Mecmuası (15 Mayıs 1926). S.4, Karar no: 9264/27.

MaarifVekâleti, Teblï̆ler Mecmuası (15 Mart 1927 ve 15 Haziran 1927). S.14 ve S.17. 
Maarif Vekilliği Tebliğler Dergisi (12 Mayıs 1941). S. 120.

Maarif Vekilliği Tebliğler Dergisi (14 Birinciteşrin 1940). S.92.

Maarif Vekilliği Tebliğler Dergisi (14 Birinciteşrin 1940). S.92.

Maarif-i Umumiye Nezareti (1330). Mekâtib-i ibtidaiye ders programı, altı, beş, dört ve ü̧ dershaneli ve muallimli mekteplere mabsus, İstanbul: Matbaa-i Amire.

Talim ve Terbiye Dairesi (05.05.1947). Karar no: 1/5612.

Talim ve Terbiye Dairesi (01.10.1945). Karar no: 3/3196.

Tedrisat-ı İbtidaiye Kanun-ı Muvakkati (1913). Madde: 13, İstanbul: Matbaa-i Âmire.

\section{İkincil Kaynaklar:}

A. Âfetinan (1998). Medenî Bilgiler ve M. Kemal Atatürk'ün El Yazıları, Ankara: Türk Tarih Kurumu Yayınları.

Afet (1930). Yurt Bilgisi Notlarımdan, Askerlik Vazifesi, İstanbul: Devlet Matbaas1.

Altınay, Ayşe Gül (2004). The Myth of Military Nation: Militarism, Gender and Education in Turkey, New York: Palgrave Macmillan.

Altınay, Ayşegül ve Tanıl Bora (2002). "Ordu, Militarizm ve Milliyetçilik", Modern Türkiye'de Siyasî Düşünce, Milliyeţ̧ilik, C.4, İstanbul: İletişim Yayınlar1.

Arming the State: Military Conscription in the Middle East and Central Asia, 1775-1925, (Ed.: Erik J. Zürcher) (1999). London: I.B. Tauris.

Ayas, Nevzad (1948), Türkiye Cumburiyeti Milli Eğitimi, Kuruluşlar ve Tarihçeler, Ankara: Milli Eğitim Basımevi.

CHP Programı (1935). Madde: 50.

Colmar Freiherr von der Goltz (1305). Millet-i Müsellaha: Asrımızın Usul ve Abval-i Askeriyesi, Çev.: Mehmed Tahir, İstanbul: Matbaa-i Ebüzziya.

Enloe, Cynthia (2007). Globalization \& Militarism: Feminists Make the Link, Lanham: Rowman \& Littlefield.

Ergin, Osman (1977), Türk Maarif Taribi, C.5, İstanbul: Eser Matbaası.

Ergün, Mustafa (1996). II. Meşrutiyet Devrinde Eğitim Hareketleri (19081914), Ankara: Ocak Yayınları.

Ezgeç, Hakkı (1942). Askerliğe Hazırlık, Erkekler İ̧in, Ankara: Mf. Yayınları.

Gökçen, Sabiha (1996). Atatürk'le Bir Ömür, Oktay Verel'in Kaleminden, İstanbul: Altın Kitaplar.

Gölpınarlı, Abdülbaki (1927). Yurt Bilgisi, İstanbul: Türk Neşriyat Yurdu. 
Kırk, David (1993). Karen Twigg, "The militarization of school physical training in Australia: the rise and demise of the junior cadet training scheme, 1911-31", History of Education, Vol. 22, No: 4, s.391-414.

Mann, Michael (1992). "The Roots and Contradictions of Modern Militarism", States, War and Capitalism, Oxford: Blackwell Press.

Ökten, Recai (1941). Askerliğe Hazırlık, Kızlar İ̧̧in, Ankara: Mf. Yayınları.

Resmi Gazete (25.01.2012). No. 28184.

Sander, M. Sadullah (1935). Yeni Yurt Bilgisi: Sinıf III, İstanbul: Resimli Ay Yayınlar1.

Sarısaman, Sadık (2003). "Birinci Dünya Savaşı sırasında ihtiyat kuvveti olarak kurulan Osmanlı genç dernekleri”, OTAM 11, s.439-501.

Somel, Selçuk Akşin (2000). The Modernization of Public Education in the Ottoman Empire, 1839-1908: Islamization, Autocracy and Discipline, Leiden: Brill Press.

Tahir, Cemil (1926). Askerliğge Hazırlık Dersleri I, İstanbul: Harbiye Mektebi Matbaası.

Tarakçıŏlu, Sait (2011). "A Failed project in Turkey's sports history: the law on physical education of 1938", The International Journal of the History of Sport, Vol. 31, No: 14, s.1807-1819.

Tarcan, Selim Sırrı (1946). Hatıralarım, İstanbul: Türkiye Yayınevi.

Toffler, Alvin (1980). Third Wave, New York: Morrow Press.

Türk Gücü Umumî Nizâmı (1329). Türkün Gücü Her Şeye Yeter, İstanbul: Matbaa-i Hayriye.

Türk Taribinin Ana Hatları I (1931). İstanbul: Devlet Matbaası.

Türkiye Cumburiyeti Maarifi 1923-1943 (1944). Ankara: Maarif Matbaas1.

Türkiye Cumburiyeti Maarifi 1940-1941(1941). İstanbul: Maarif Matbaas1.

Ute, Frevert (2004). A Nation in Barracks, Modern Germany, Military Conscription and Civil Society Oxford: Berg Press.

Ünder, Hasan (1998). "Kemalizmin Işı̆̆ında, Atatürk Döneminde Eğitsel Değerler”, yayımlanmamış doktora tezi, Ankara: Ankara Üniversitesi.

Vagts, Alfred (1959). A History of Militarism: Civilian and Military, London: Meridian Books.

Weber, Eugene (1976). Peasants into Frenchmen: The Modernization of Rural France, 1870-1914, Stanford: Stanford University Press.

Yaman, Kadri (1937). Yurt Müdafaasında Türk Gençliği, İstanbul: Devlet Matbaasi.

Yücel, Hasan Âli (1994). Türkiye’de Orta Öğretim, Ankara: Kültür Bakanlığ1 Yayınlar1. 


\section{ABSTRACT \\ Starting Excessive Militarism in The Turkish Educational System (1926-1947)}

With the invention of modern countries, a mandatory relationship and interaction has emerged between compulsory education, compulsory military service and the practices of citizenship. Being a loyal citizen to the country required a disciplined, central and compulsory education.In the $19^{\text {th }}$ century when greatness was linked with armament, education was the most useful tool to increase the number of soldiers and social mobilization. For this reason, rituals and practices in favor of military service were included in education programs. It was sometimes seen in programs alone while sometimes integrated into courses such as Physical Education, Gymnastics, History, and Geography. Ottoman Empire after the second half of the $19^{\text {th }}$ century was not out of these developments. Military education and paramilitary organizations which became popular during the First World War gained another dimension in the Republic Period. Military service became a compulsory course after 1926 and turned into a practice including 20 day camp on every educational level. Military Service Course which has a large part in shaping the social and mental world of today is a non-investigated topic in Turkish educational history. In this article, Preparatory for Military Service course between the years 1926 and 1947 have been analyzed by using archival documents.

Keywords: Education, Militarism, Paramilitarizm, Physical Education, Turkish Educational System 
